\title{
CONCEPTS OF EVENT LOYALTY \& DESTINATION LOYALTY BASED ON THE EXAMPLE OF SPORTS FANS OF POZNAN HALF MARATHON
}

\author{
JOANNA POCZTA, ${ }^{1}$ EWA MALCHROWICZ-MOSKO, ${ }^{2}$ NUNO ALMEIDA ${ }^{3}$ \\ ${ }^{1}$ University of Physical Education in Poznan, Department of Tourism and Recreation \\ e-mail: jpoczta@awf.poznan.pl \\ ${ }^{2}$ University of Physical Education in Poznan, Department of Tourism and Recreation \\ e-mail: malchrowicz@awf.poznan.pl \\ ${ }^{3}$ Polytechnic of Leiria and University of Coimbra \\ e-mail: nunoalmeida@ipleiria.pt
}

\section{JEL CODES | I, I3, I31}

KEYWORDS destination loyalty, event loyalty, half marathon

ABSTRACT This article explores the research problem of building loyalty of tourists towards sports events and tourist destinations, whose roots are in behavioral marketing. The work includes an overview of literature focused on tourist loyalty towards a sports event, and further on - towards a tourist destination. It presents the concepts which made it possible to create assumptions for conducting empirical research during the $6^{\text {th }}$ Poznan Half Marathon. The aim of the study was to determine the factors influencing the spectators' loyalty towards this event and subsequently towards the destination. The study focused on the attempt to determine whether loyalty can be built also among sports fans, because foreign language publications are typically concerned with athletes. It appears that the conducted research confirms the assumptions adopted on the basis of the literature and proves that the loyalty of a sports fan towards the event is influenced by: motivations for passive participation in the event ( $p u s h$ and pull), socio-demographic factors, and a sense of satisfaction from supporting the athletes, who are often close to them.

\section{Introduction}

Research into the loyalty of consumers most frequently appears in the marketing literature, and conducting such research has been recognized as one of the most important steps to the success of businesses (La Barbara, Mazursky, 1983; Turnbull, Wilson, 1989). Hallowell (1996, pp. 27-42) proved that there is a link between customer satisfaction, customer loyalty and service provider's profitability. The author claims that loyal customers cause a reduction of the cost of recruiting 
the new ones, their sensitivity to price and maintenance costs. From the standpoint of traditional marketing of products and services, loyalty can be measured by means of repeat sales or service referrals to other new consumers, but it is the satisfaction with the products or services that has the greatest impact on consumer loyalty (Pine, Peppers, Rogers, 1995; Bitner, 1990). Loyalty also occurs due to another, mundane reason - consumers have less and less free time, and this makes them try to simplify the decision-making process concerning purchases by acquiring known and proven products or services.

The analysis and exploration of this concept in tourism research has a relatively short history, and the notion of destination loyalty rarely appears in the literature. However, the researchers dealing with this issue consider it justified to understand what factors increase the loyalty of tourists towards the place they visited. This information is valuable for service providers providing tourism services (Flavian, Martinez, Polo, 2001). From a marketing point of view, it is less costly to put work in stopping a tourist, and to put work to get the tourist back to a destination again than to encourage to come and attract the new ones (Um, Chon, Ro, 2006). In addition, Baker and Crompton (2000, pp. 785-804) prove in their research that there is a strong relationship between consumer loyalty and profitability, showing that this is the reality of the tourism industry. Attaching a tourist to the place is simpler than encouraging new visitors to arrive.

The results of the research into factors which influence tourist loyalty have shown that the return visit is dictated by the high number of previous visits of a given place (Mazursky, 1989; Court, Lupton, 1997). However, apart from the knowledge of the destination, a significant factor is the overall satisfaction of the tourist with the tourism experience in a specific destination, considered as a prognostic factor, which is linked to the established intention of the tourist declaring their desire to target this destination again (Oh, 1999; Kozak, Rimmington, 2000; Bowen, Bigné, Andreu, 2004). The authors Yoon and Uysal (2005, pp. 45-56) emphasize the fact that tourist destinations can be perceived by tourists as a product and recommended to other potential visitors (including friends and family).

The development of sports tourism contributes to building the destination loyalty through sports events that attract not only rival competitors, but also crowds of fans and tourists. Among them, there are passive sports tourists - fans who are faithful to events and athletes. It is therefore worth defining the important factors influencing the loyalty of the fan of a running event towards the event and the city in which it is taking place, as well as checking whether the concepts of event loyalty and destination loyalty are ever present among the fans (and not just the athletes). This becomes of particular interest when the previous travel motives fail to predict loyalty intentions (Halpenny, Kulczycki, 2016). Furthermore, the social impacts of events can help to improve satisfaction in order to build loyalty (Yürük, Akyol, 2017, p. 376). 


\section{Motivations, emotions, and sense of satisfaction - significent variables in the study of loyalty towards a tourist destination}

In the literature, some comprehensive models for explaining loyalty towards the tourist destination have emerged. For example, Yoon and Uysal (2005, pp. 45-56) have proposed a model which binds loyalty towards destinations with travel satisfaction and motivation to go on holiday. These studies show a significant cause and effect relationship between the satisfaction of staying at the destination and loyalty, as well as between motivation to travel and satisfaction from travel. Another author - Oh (1999, pp. 67-82) stated that service quality, price value, perception of the value for the customer, and perception of company performance are all determinants of customer satisfaction. If customers are satisfied with them, they will show their intentions to visit the place again. Similarly, Bigne and co-authors (2004, pp. 682-696) state that declarations of return and willingness to recommend a particular place are influenced by the quality of tourism services and the image of a destination. Oom do Valle et al. $(2006,28)$ elaborated a model which presents a direct cause and effect relation between the satisfaction of the tourist with the target loyalty intention. It turned out that it is the motivations which are the basis for the decision-making process of the trip and therefore they should also be taken into account when analyzing loyalty intentions. Beerli and Martin (2004, pp. 623-636) argue that motivation is a need which drives the individual to act in a certain way so as to achieve desired satisfaction. We can distinguish push and pull motivation (Crompton, 1979). ${ }^{1}$ Yoon and Uysal (2005, pp. 45-56) recognize the satisfaction of travel as a variable which is the mediator between push and pull motivations and the loyalty towards a destination. However, the impact of the socio-demographic variables on the decision-making process regarding the use of tourism services concerns yet another important issue. Studies have shown that age and the level of education affect the choice of travel destination and they are the variables which are determinants in the decision-making process.

\section{Concepts of destination loyalty and event loyalty with reference to sports tourism}

With regard to active sports tourists - athletes (e.g. runners), Sato, Jordan and Funk (2016) prove that participation in running events has a direct impact on the sense of life satisfaction and they connect it with loyalty towards the organized running event, the psychological aspect of participation and the impact of preparations for the event on health and well-being. The studies show that satisfaction from the tourist experience in a specific place is the indicator of the next visit and influences loyalty behaviors. Taking into account the results of their research and growing popularity of sports tourism, especially sports events tourism (including running events), it was decided to

\footnotetext{
${ }^{1}$ Push and pull motivations - push motivation is the motivation that we impose on us ourselves. For example, an athlete decides to train for a year to run in the marathon. Pull motivation is the motivation which we cannot influence because we feel it inside us - for example, an artist paints a lot of pictures because it is his passion, he senses great satisfaction doing that and he is practically not able to resign from it. With respect to tourism, push motivation is triggered by such factors as attractiveness of the destination - for example beaches, recreation facilities and cultural attractions. On the other hand, pull motivation is the expression of the internal expectations of an individual, which are considered individually.
} 
propose a similar approach, but concerning the fans of these events (i.e. their passive participants). A review of the literature on the analyzed research problem indicates a great significance of: sociodemographic variables such as age, education; life satisfaction (also affected by current professional situation); motivations (push and pull) and a sense of pride and gratification. Therefore, a conceptual model taking into account the findings of other researchers, specifying variables and preparation for the study among sports tourism participants, is proposed below.

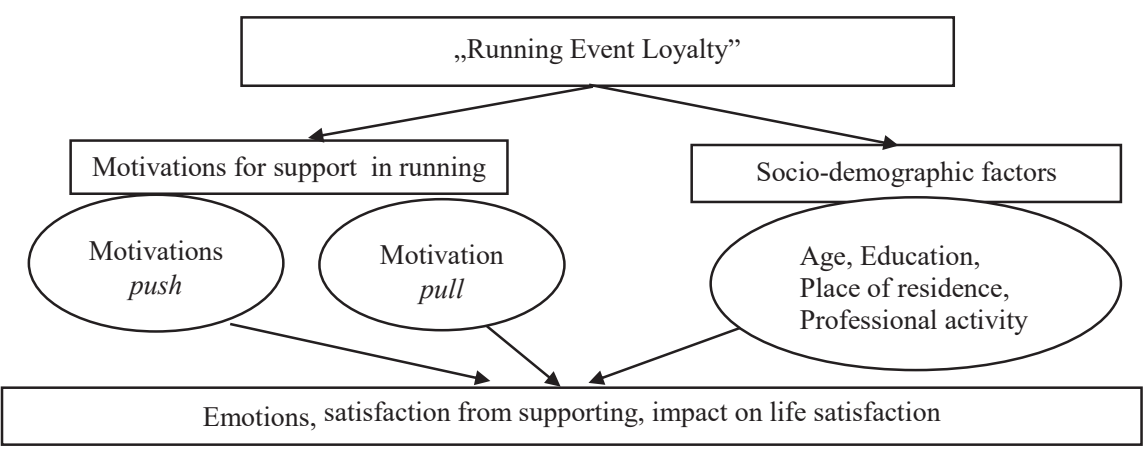

Figure 1. Conceptual model - loyalty of fans, sports tourists towards a running event

Source: own elaboration.

The model shows variables which have a direct impact on the loyalty of sports tourists who support sports events towards a mass running event (e.g. half marathon). The pull motivations include: social interactions (supporting family and friends participating in sports rivalry, supporting athletes, meeting new people, time spent with friends, conversations with foreigners and people in other areas, sense of integration, etc.); change of the environment, being in a new situation (escape from everyday life, refreshing the mind, emotions connected with watching the competition); family aspects (strengthening of family ties through common active and passive participation in the event, support, sense of pride in their loved ones); positive emotions (excitement, satisfaction, pride of the athletes). Push motivations include: city resources (attractiveness and atmosphere of the place, route and atmosphere of the race, visible efforts of the organizers); culture (local food, traditions, local community, history of the city); services (recreation, tourism, gastronomy, entertainment, transport accessibility, etc.). Highly significant socio-demographic factors including age, education, professional activity, and place of residence were also taken into account. Meeting all the above factors results in giving the tourists a feeling of satisfaction and fulfillment in life. Emotions are present in tourist activity and tourist behavior represents an important starting point to explore the content analysis (Santos, Ramos, Almeida, 2014). In that way the content of the $6^{\text {th }}$ Poznan Half Marathon represents an opportunity to study the role of the emotions. The research carried out during the $6^{\text {th }}$ Poznan Half Marathon by the diagnostic survey method using a standardized interview technique was conducted on 510 sports fans. The sample was selected in such a way 
as to ensure good representativeness of the obtained results. A scheme of simple random sampling without replacement was used. The study was conducted during Poznan Half Marathon, which is one of the most important running events in the field of mass sport in Poland. Apart from sharing the emotions resulting from running, half marathon gives you the opportunity of a joint trip to the venue of the event. In this case, push motivations (culture, history, atmosphere and overall attractiveness of Poznan) play an important role. A running event is an attraction, a magnet that attracts the same athletes/consumers even several times in their lifetime. However, in such a trip, the athletes are followed by their fans who become tourists in the destination and also take advantage of the offer of the host city.

\section{Empirical research results - a socio-demographic profille of a fan of the Gth Poznan half-marathon}

The empirical studies covered 510 half-marathon fans (256 inhabitants, 254 tourists), with women predominating (64.7\%). Male fans accounted for $35.3 \%$ of the respondents. The majority of the respondents were young people of working age. $41.4 \%$ of the respondents were at the age of $19-25$ years, $27.8 \%$ were aged $26-35$ years, $13.9 \%$ of the respondents were aged $36-50$ years, $9 \%$ of the respondents $-51-70$ years, $7.5 \%$ of the respondents were at the age of 18 and less, and $0.4 \%$ of the respondents were 71 years older and above. As far as education is concerned, the surveyed fans of the $6^{\text {th }}$ Poznan Half marathon most frequently declared higher education with master's degree (44.5\%), followed by higher professional education declared by $14.7 \%$ of the respondents, secondary education $-32.2 \%$, primary $-5.9 \%$ and vocational $-2.7 \%$. More than half of the surveyed fans were actively employed at the time of the survey (50.6\%), student status was declared by $31.8 \%$, every tenth respondent was a school pupil (10\%), 4.9\% were unemployed, and $2.7 \%$ were pensioners. The highest percentage of the fans surveyed was working persons (more than half $-50.6 \%$ ).

What is also interesting it is the place of origin from which the surveyed fans came to participate in the race (Figure 2). Among the fans of half marathon who took part in the survey, 44.3\% were residents of Poznan. 34.5\% were residents of other places in Wielkopolska (Great Poland region), $18.2 \%$ of fans came from outside Wielkopolska, and almost 3\% were foreigners who came from abroad.

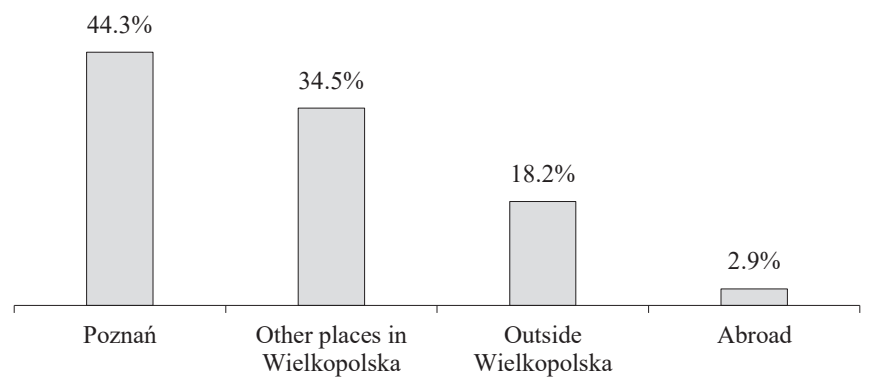

Figure 2. Place of residence of all fans surveyed (tourists + local residents)

Source: own study based on the conducted research $n=510$. 
More than half of the surveyed fans (55.7\%) were visitors. This event is therefore an event which stimulates the development of sports fan-tourism. The Poznan Half Marathon is attended by both Polish and foreign fans coming to Poznan. However, the rank of the event is rather regional. This is reflected in the results of the presented research. Most of the half marathon fans were city dwellers from cities with over 500 thousand inhabitants (48\% - nearly half). Then they were village residents (17.3\%), residents of cities with 10-100 thousand inhabitants (16.1\%), towns up to 10 thousand inhabitants (12.4\%), and cities with 100-500 thousand inhabitants (6.3\%). Summing up, the socio-demographic profile of the passive participant of the 6th Poznan Half Marathon is dominated by young women (aged 19-35) with higher education, working actively in their professions and big city residents.

\section{Motivations for passive participation in the race - support, sports rivalry, impact on emotions}

The motivations of the Half Marathon participants identified during the conducted study include: support for the persons close to the fan through cheering, social interactions, change of the environment, and numerous positive emotions triggered by watching the athletes and their rivalry. The subsequent graphs below show the role played by cheering in the mass running event. They are, above all, positive.

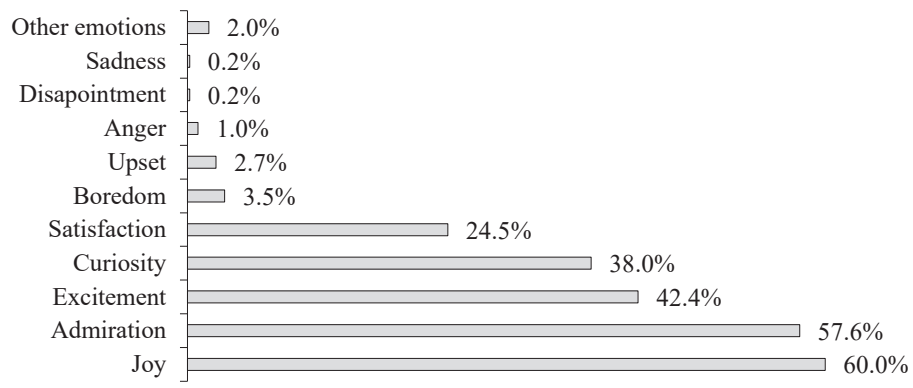

Figure 3. Emotions accompanying cheering on 6th Poznan Half Marathon $(\mathrm{n}=510)$

Source: own elaboration.

The feelings which dominated among the fans on the day of the half marathon race were definitely positive. As many as $60 \%$ of the respondents were joyful, $57.6 \%$ felt admiration, $42.4 \%$ were excited, 38\% were curious, $24.5 \%$ satisfied. Boredom was felt by $3.5 \%$ of the respondents, upset by $2.7 \%$, anger $-1 \%$, disappointment $-0.2 \%$, sadness $-0.2 \%$, other emotions were felt by $2 \%$, and included: arousal (1 person), affection (2), frustration due to cold (1), pride in the beloved person (6). These emotions are also dominant during the entire 3-day period of the event. More than half $-51.8 \%$ - of the respondents felt joy, $38.2 \%$ felt admiration, $37.1 \%$ - curiosity, $29.8 \%$ - satisfaction, 
$29.4 \%$ - excitement, $2.9 \%$ - upset, $1.6 \%$ - boredom, $0.6 \%$ - anger, $0.4 \%$ - disappointment, $0.4 \%$ sadness, $1 \%$ - other emotions including: pride (4), indifference (1).

Almost all respondents (99.4\%) also found that supporting the half-marathon allows for sharing emotions with other people, and only $0.6 \%$ of respondents disagreed in this question.

The respondents stated that support and cheering during the half marathon is an opportunity to share emotions with other people and to integrate with them on average at the level of 7.6 points. The fans were also asked about the level of satisfaction from passive participation in the event - as fans. It turns out that on the grading scale 1 to 10 as much as $32.2 \%$ indicated the highest grade. Fans were satisfied with participating in a sports event on average at 8.1 points on a 10 -degree Likert scale.

In addition, as many as $40.4 \%$ of the fans felt that participation in the half marathon had a great impact on their life satisfaction. 34.5\% said the impact was moderate. Over a tenth of the surveyed persons $(12.9 \%)$ considered that the impact was very high. $7.6 \%$ stated that there was no impact at all, $3.7 \%$ described it as low, and $0.8 \%$ - as very low.

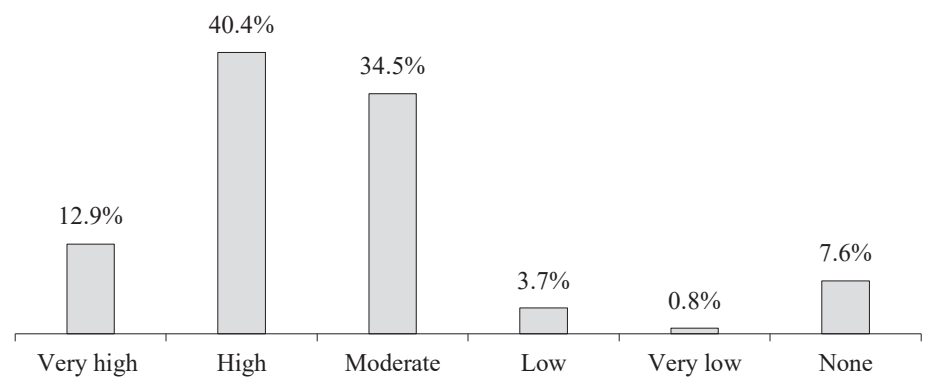

Figure 4. Assessment of the impact of cheering on half marathon on life satisfaction felt $(n=510)$

Source: own elaboration.

Therefore, sports events are worth organizing because they affect all participants, probably directly the athletes, but it turns out that also the fans. They increase the level of their satisfaction with life (more than a half of respondents answered so $-53.3 \%$ ).

According to research conducted during this event in Poznan, 62.7\% of the respondents supported the sports event for the first time in their lives. For $37.3 \%$ this was another time (the second time - for $19.4 \%$ of the respondents - i.e. every fifth fan, the third time - for $8.4 \%$, the fourth time for $3.3 \%$, the fifth time or more - for $6.1 \%$ ). These are very significant data showing that the loyalty towards the event and the destination in which it is held may also be related to passive participants in the competition - the fans. $37.3 \%$ - such a percentage of respondents took part in the event for another time - as a supporter. The results of the research show that out of 510 respondents, $78.4 \%$ supported their family and friends. More than one in five respondents $(21.6 \%)$ cheered on the event despite the fact that no one close to them was in the competition. 
Most of the fans are in the company of others. Nearly half of the respondents cheered in a larger group of 3-5 people (46.5\%). More than $30 \%$ of respondents participated passively in the half marathon in the company of another person (as 2 persons), $11.8 \%$ (every tenth person) - alone, $5.3 \%$ (every twentieth person) - in the group of more than 10 people, and $4.9 \%$ - in the group of 6-10 people. These results are very significant from the tourist and economic point of view.

Most respondents declare their willingness to participate again. Thus, positive emotions and a sense of satisfaction affect this declaration already during the sports event.

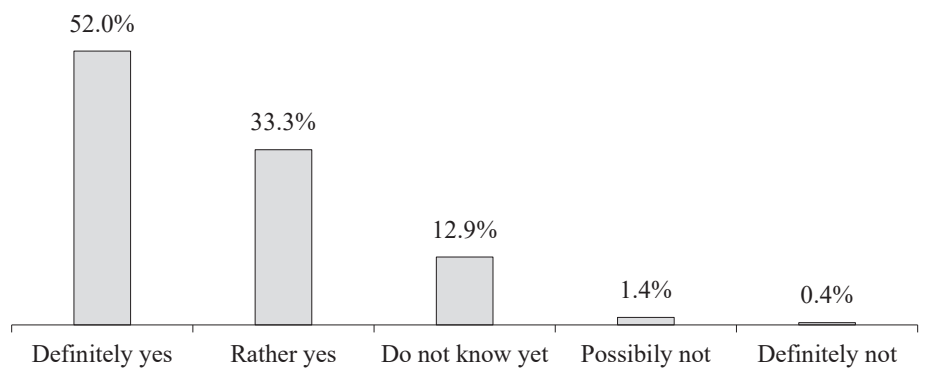

Figule 5. Intention to participate again as a supporter in half marathon in Poznan $(\mathrm{n}=510)$

Source: own elaboration.

As many as $85.3 \%$ of the spectators intend to take part in the half marathon in Poznan in the future (52\% - "definitely yes", 33.3\% - "rather yes"). 12.9\% do not know yet, 1.8\% of respondents reject such a possibility. This is a very optimistic result from the point of view of tourism. Such a declaration is undoubtedly influenced also by the high level of organization of the event, as more than $30 \%$ indicated the highest rating on a scale of 1 to 10 points. The level of organization of the event was assessed on average by fans at the level of 8.3 points.

It appears that for $95.3 \%$ of the respondents, participation in the half marathon as a supporter was the main motive for the arrival in Poznan $(n=254)$. However, this event and cheering motivated by giving support to a close person - a runner, contributed to taking part by the respondents in the short-term tourist movement.

\section{Conclusion}

The conducted study positively verified the proposed conceptual model concerning fan loyalty, including the loyalty of passive sports tourists towards a running event (Figure 1). Research confirms that the satisfaction of cheering in a particular event organized cyclically in the same place:

- in the case of tourists, it affects the sense of satisfaction and contentment with life, and in this case is a determinant of the tourist re-visit,

- fans-tourists are also motivated to come and participate in the event not only by an event itself, but also by a positive, sporting image of the city and its tourist attractiveness, 
- participating in the event as a fan contributes to spending time at the destination as a tourist and enjoying the cultural, entertainment and recreational offer. Sports events therefore significantly drive tourist movement.

The research confirms the significance of socio-demographic variables such as age, education, life satisfaction (also affected by current occupational status); motivations ( $p u s h$ and pull) and a sense of pride or admiration for the dear and near ones participating in the event, and a sense of satisfaction. Positive emotions connected with participation in the event, a positive image of the city, tourist activities undertaken during a short stay, give a sense of satisfaction, fulfillment in life and build the event loyalty in a tourist, i.e. loyalty behaviors of a sports tourist towards (organizers) of a given race and destination (destination loyalty), where the race is organized. Therefore, the concepts presented in the article describe the phenomena that also occur among the fans and not just among the active participants of the half marathons (athletes).

\section{References}

Baker, D.A., Crompton, J.L. (2000). Quality, satisfaction and behavioral intentions. Annals of Tourism Research, 3 (27), 785-804.

Beerli, A., Martín, J.D. (2004). Tourists' characteristics and the perceived image of tourist destinations: a quantitative analysis - a case study of Lanzarote, Spain. Tourism Management, 5 (25), 623-636.

Bigné, J.E., Andreu, L. (2004). Emotions in segmentation: an empirical study. Annals of Tourism Research, 3 (31), $682-696$.

Bitner, M.J. (1990). Evaluating service encounter: the effects of physical surroundings and employee responses. Journal of Marketing, 54, 69-82.

Bowen, D. (2001). Antecedents of consumer satisfaction and dis-satisfaction (CS/D) on Long-Haul inclusive tours: a reality check on theoretical considerations. Tourism Management, 22, 49-61.

Court, B., Lupton, R. (1997). Customer portfolio development: modelling destination adopters, inactives, and rejecters. Journal of Travel Research, 1 (36), 35-43.

Crompton, J.L. (1979). Motivations for pleasure vacation. Annals of Tourism Research, 4 (6), 408-424.

Flavian, C., Martinez, E., Polo, Y. (2001). Loyalty to grocery stores in the Spanish market of the 1990s. Journal of Retailing and Consumer Services, 8, 85-93.

Hallowell, R. (1996). The Relationship of Customer Satisfaction, Customer Loyalty, Profitability: An Empirical Study. International Journal of Service Industry Management, 4 (7), 27-42.

Halpenny, E., Kulczycki, C., Moghimehfar, F. (2016). Factors effecting destination and event loyalty: examining the sustainability of a recurrent small scale running event at Banff National Park. Journal of Sport \& Tourism, 3-4 (20), 233-262.

Kozak, M., Rimmington, M. (2000). Tourism satisfaction with Mallorca, Spain as an off-season holiday destination. Journal of Travel Research, 3 (38), 260-269.

La Barbara, P.A., Mazursky, D. (1983). A Longitudinal Assessment of Consumer Satisfaction/Dissatisfaction: The Dynamic Aspect of the Cognitive Process. Journal of Marketing Research, 20, 393-404.

Mazursky, D. (1989). Past experience and future tourism decisions. Annals of Tourism Research, 16, 333-344.

Oh, H. (1999). Service quality, customer satisfaction, and customer value: a holistic perspective. International Journal of Hospitality Management, 18, 67-82.

Santos, V., Ramos, P., Almeida, N. (2014). Consumer behaviour in tourism: A content of analysis of relationship between involvement and emotions. Journal of Tourism Research, July.

Sato, M., Jordan J.S., Funk D.C. (2016). A distance-running event and life satisfaction: The mediating roles of involvement. Sport Management Review. 
Turnbull, P., Wilson, D.T. (1989). Developing and protecting profitable customer relationships. Industrial Marketing Management, 18, 233-238.

Um, S., Chon, K., Ro, Y. (2006). Antecedents of revisit intention. Annals of Tourism Research, 4 (33), $1141-1158$.

Yoon, Y., Uysal, M. (2005). An examination of the effects of motivation and satisfaction on destination loyalty: a structural model. Tourism Management, 1 (26), 45-56.

Yürük, P., Akyol, A. (2017). Analysing the effects of social impacts of events on satisfaction and loyalty. Tourism Management, 60, 367-378.

\section{KONCEPCJE EVENT LOYALTY \& DESTINATION LOYALTY NA PRZYKŁADZIE KIBICÓW PÓŁMARATONU}

SŁOWA KLUCZOWE

STRESZCZENIE lojalność wobec destynacji, lojalność wobec eventu, półmaraton

Artykuł przedstawia problem badawczy, którego korzenie znajdują się w marketingu behawioralnym. Praca zawiera przegląd literatury skoncentrowanej na lojalności turysty wobec eventu sportowego, a w dalszej kolejności wobec destynacji turystycznej. Przedstawione zostały koncepcje, które umożliwiły stworzenie autorskich założeń badawczych, modelu koncepcyjnego i przeprowadzenie badań podczas 6. Poznań Półmaratonu. Celem badań było określenie istotnych czynników wywierających wpływ na lojalność kibica wydarzenia biegowego wobec tego eventu. Okazuje się, ze przeprowadzone badania potwierdzają przyjęte na podstawie literatury założenia i dowodzą, że na lojalność kibica wobec wydarzenia biegowego wpływają: motywacja do biernego udziału w biegu, czynniki socjo-demoraficzne oraz poczucie satysfakcji z kibicowania sportowcom, często bliskim osobom, a w konsekwencji podniesienie satysfakcji z życia. 